\title{
Besondere Gawes van die Heilige Gees
}

\author{
M J DU P BEUKES
}

\section{Die Pinkstergroepe}

Sedert die begin van die twintigste eeu het daar 'n nuwe belangstelling ontstaan vir die besondere gawes van die Heilige Gees. ' $n$ Sterk drang het onder gelowiges begin heers om op 'n besondere wyse die werking van die Heilige Gees te ervaar. Dit het 'n ernstige strewe geword om soos die Christene op die eerste Pinksterdag vervul te word met die Heilige Gees en daarna te spreek in tale en siekes te genees. Weldra het gelowiges verklaar dat hulle met die Heilige Gees gedoop is en dat genoemde resultate daarna voorgekom het. Hierdie hele gebeure het tot gevolg gehad dat daar "pinkstergroepe" of "pentacostaliste" ontstaan het naas die gevestigde kerke.

Hierdie groepe openbaar besondere kenmerke:

Hulle getuig dat hulle met die Heilige Gees gedoop is, daarna in tale gespreek het en dat siekes by daardie geleentheid op groot skaal genees is;

die werk van Jesus Christus en die Heilige Gees word van mekaar geskei;

hierdie besondere besit van die Heilige Gees en die daarmee gepaardgaande spreek in tale en wondergenesings word beskou as kenmerke van 'n ware gelowige;

voortdurend roem hulle op die gawes wat hulle besit;

die ander gawes wat in die Bybel vermeld word, neem by hulle geen plek in nie. Die ander gawes word gereken as behorende tot die gewone, die alledaagse;

hulle aanvaar nie die kerk as instituut nie, maar slegs as ' $n$ vergadering van gelowiges. Hulle erken nie die geïnstitueerde ampte nie, maar alleen die "garismatiese" leierskap;

tydens hulle eredienste is daar geen vaste liturgie nie. Hulle ken feitlik geen "liturgiese kerklike jaar" nie. Alles word oorgelaat aan die inisiatief van die plaaslike voorganger. In teenstelling met ons eredienste, word sterk klem gelê op die deelname van almal. Individuele gebede, getuienis en ' $n$ bevestigende amen op alles wat gebeur, is kenmerkend. Popmusiek word gespeel en hallelujas gesing. Gebedsbyeenkomste, Bybelstudie-aande en genesings byeenkomste word ver bo 'n gewone erediens gewaardeer; die 
swaartepunt van alles is die subjektiewe en individuele en nie die objektiewe en gemeenskaplike nie;

die spoedige weerkoms van Christus word sterk beklemtoon; vas en die gee van tiendes kom feitlik algemeen voor;

Woord en Gees word van mekaar geskei. Die besondere belewenis van vervul wees met die Heilige Gees neem so 'n besondere plek in dat die Woord op die agtergrond geskuif word. Kennis van God en sy wil, asook kennis van 'n ander se geestestoestand word beskou as direk toeganklik van weë die besondere besit van die Heilige Gees. Adrie Terblanche van Durban sê onder andere die volgende ten opsigte van Johnny Greyling deur wie se bemiddeling sy tot bekering gekom het: "He said that while passing the restaurant, the Holy Spirit guided him to me and revealed my past life to him" (Bond, Tydskrif van die Bond van Pinkster Sakemanne Internasionaal, vol 2, nr 2, April-Junie 1974, bl 5).

Verskeie faktore word genoem wat aanleiding gegee het tot die ontstaan van die pinkstergroepe. Die volgende aanklagte word gewoonlik teen die gevestigde kerke gerig:

Verwaarlosing en geringskatting van die Heilige Gees en sy werk; koue formalisme en die geringskatting van emosionele ervarings; die gevestigde kerk is te veel 'n georganiseerde "domineeskerk", die klem val te veel op die besondere ampte terwyl die gewone lidmaat passief op die agtergrond bly.

Aanvanklik het die "pinkstergesindes" hoofsaaklik voortgekom uit die nywerheidsektor. Geleidelik het dit verspreid geraak en kom vandag voor onder alle sektore van die samelewing. Blignaut de Villiers 'n koerantman uit Port Elizabeth, getuig die volgende van sy bekering: "Nooit was 'n predikant naby my nie. Altyddeur was dit net die stem van God wat gesê het: Nou is dit genoeg. Ek het daardie nag bitter lank gebid, my lewe aan God opgedra. Ek het geween soos nog nooit in my lewe nie. Kort daarna het God sy Heilige Gees in my uitgestort en ek het in 'n onbekende hemelse taal gespreek." (Bond, a w, bl 4). "Bond" doen veral besonder moeite om getuienis te gee van Afrikaanssprekendes en gegradueerdes. Volgens 'n onlangse opname blyk dit dat die pinkstergesindes soos volg verspreid is: uit die nywerheidsektor $49 \%$, besigheids- $18,7 \%$ en professionele mense $17,4 \%$. Dit is ook nie beperk tot 'n bepaalde ouderdomsgroep nie. Bo 40 jaar $35,5 \%$; tussen 25 en 40 jaar $32,3 \%$; onder 25 jaar $32,5 \%$. Onder laasgenoemde groep is studente prominent verteenwoordig met $12,3 \%$.

Waar die pinkstergesindes aanvanklik groepe los van die kerk gevorm het, kom hulle nou selfs binne die gevestigde kerke voor. Veral uit die geledere van die Rooms Katolieke word besonder melding ge- 
maak van hierdie verskynsel. So groot is die omvang van hierdie verskynsel dat daar vandag al hiervan gepraat word as 'n "wêreldverskynsel". (A significant revival is now in progress around the world. Not only is it crossing national frontiers - it is crossing denominations frontiers too. Anglicans, Baptists, Congregationalists, Lutherans, Methodist and Presbyterians are being caught into this great movement",) (Bond, a w, bl 14). Dit is hoegenaamd nie vreemd om in "Bond" te lees van lidmate wat nog amptelik deel is van die gevestigde kerke wat hulle agter die gedagtes van die "pinkstergesindes" geskaar het nie. Roy Yates, 'n professionele gholfspeler en lidmaat van die Anglikaanse Kerk, verklaar: "On January 13th 1973, the Bond Business mens's fellowship had a convention in Pietersburg, and God Mighty baptised me in the Holy Spirit and I spoke in tongues."

Gedurende 1974 is 'n omvattende ondersoek gedoen na hierdie verskynsel in die Afrikaanse kerke in Suid-Afrika. (Hierdie werk is gedoen deur die Kaapse predikante wat deel is van die werkgemeenskap Praktiese Teologie van Suid-Afrika.) Volgens die resultate kom hierdie verskynsel slegs in geïsoleerde gevalle binne die drie susterkerke voor: Die ondersoek is beperk tot $37,1 \%$ van die totale gemeentes van die drie kerke. In $71,2 \%$ van die gemeentes kom dit glad nie voor nie. In 174 gemeenes kom dit wel voor. In die Nederduitse Gereformeerde Kerk word melding gemaak van 141 gevalle, in die Hervormde gemeentes 22 en in die Gereformeerdes 11. Tydens die kongres het verskeie predikante gepleit vir die aanvaarding van hier "garismatiese" as gewone, wel toelaatbare verskynsel in die kerk. Ander het die aanmoediging daarvan bepleit. Een het self getuienis gegee dat hy self in tale spreek. Ander het sterk afwysend daarteenoor gestaan. In die reeds genoemde tydskrif Bond word voortdurend getuienis gegee van persone wat hierdie besondere "garismatiese" binne ons drie susterkerke beleef en word lidmate ook aangemoedig om deel te neem daaraan.

As die totale aantal lidmate wat hulle reeds geskaar het by die gedagtes van die pinkstergroepe, in aanmerking geneem word, is dit nie baie groot nie. As bloot gelet word op die klein getal, moet ons die beweging binne ons Kerk van so 'n geringe aard beskou, dat dit nie eers besondere ondersoek regverdig nie. Die feit dat dit wel voorkom en die kommer wat by baie gelowiges heers dat die reeds bestaande teologie van die kerk, miskien op 'n dwaalspoor kan wees, regverdig grondige ondersoek. Sondermeer goedkeuring van hierdie "pinkstergedagtes" en daarmee gepaardgaande beywering vir hierdie gawes is net so onhoudbaar as afkeuring daarvan sonder dat die hele saak eers deeglik ondersoek is, in die lig van die Skrif.

\section{Gawes van die Gees}

Op grond van enkele gegewens uit die Evangelies en Handelinge 
kom die pinkstergroepe tot hierdie konklusie: Geen mens is 'n ware gelowige as die Heilige Gees nie opnuut oor hom uitgestort is, as hy nie gedoop is met die Heilige Gees en daarna in vreemde tale gespreek het nie. Besondere klem word deur hulle gelê op die begrippe "doop met die Heilige Gees" en met die Heilige Gees "vervul" wees.

Die uitdrukking doop met die Heilige Gees kom net sewe maal voor in die Nuwe Testament naamlik in Matteus 3:11; Markus 1:8 en Lukas 3:16. In hierdie tekste sê Johannes die Doper ten opsigte van Jesus Christus dat Hy hulle sal doop met die Heilige Gees en met vuur. In Johannes 1:33 is dit weer Johannes wat 'n soortgelyke uitspraak met betrekking tot Jesus Christus maak: "Dit is Hy wat met die Heilige Gees doop". In Handelinge 1:5 sê Jesus: "Want Johannes het wel met water gedoop, maar julle sal met die Heilige Gees gedoop word, nie lank na hierdie dae nie." In Handelinge 11:16 verwys Petrus terug na die woorde van Jesus soos vervat in Handelinge 1:5. Paulus sê: "Want ons is almal ook deur een Gees gedoop tot een liggaam." (I Kor 12:13). Die "deur" kan net sowel vertaal word met "in" of "met".

Uit genoemde tekste is dit duidelik dat die begrip "doop met die Heilige Gees" ' $n$ belofte is wat Jesus Christus self aan sy apostels gegee het. In Lukas 24:49 kry ons dieselfde belofte net in ander woorde: "Maar julle moet in die stad Jerusalem bly totdat julle toegerus is met krag uit die hoogte."

As ons let op die besondere belofte in verband met die Heilige Gees, soos vervat in Johannes 14:16, is dit duidelik dat die Heilige Gees eers uitgestort sou word na Christus se hemelvaart. As ons let op die feit dat doop met die Heilige Gees en doop met vuur saamgaan en hiermee saam die besondere manifestasie van vuurtonge op Pinksterdag onthou, is dit ongetwyfeld waar dat die begrip "doop met die Heilige Gees" dui op die uitstorting van die Heilige Gees op Pinksterdag.

Deurslaggewend in hierdie hele diskussie sal daarom die uitstorting van die Heilige Gees wees, soos dit vir ons beskryf word in Handelinge.

Naas die belofte van die Heilige Gees, gee Christus ook aan sy apostels opdrag om sy getuies te wees in "Jerusalem, sowel as in die hele Judea en Samaria en tot aan die uiterste van die aarde" (Hand 1:8). As ons let op die besondere geleenthede waar daar sprake is van uitstorting van die Heilige Gees in Handelinge, sien ons dat dit telkens net gebeur as daar sprake is van 'n nuwe terrein waar die evangelie verkondig word en mense tot die geloof kom. Die Heilige Gees, as ons dit so mag stel, loop die pad wat in Handelinge 1:8 gegee word.

Op Pinksterdag, as 'n groot skare byeen is, word die Heilige Gees uitgestort (Hand 2:1-13). Dit gaan gepaard met 'n geweldige ruk- 
wind, tonge van vuur en apostels wat in vreemde tale spreek. Die natuurverskynsels is teken van die onkeerbare krag van die Heilige Gees. Die tale wat gespreek word, is volgens alle gesaghebbende kommentare, nie onverstaanbare brabbeltaal nie, maar 'n verstaanbare bestaande taal. Dit word beklemtoon deurdat die skare uitroep: "En hoe hoor ons hulle, elkeen in ons eie taal waarin ons gebore is" (Hand 2:8).

Hierdie spreek in tale het om 'n besondere rede plaasgevind. Dit het gebeur sodat elkeen wat daar teenwoordig is die evangelie van Jesus Christus kon hoor. Sodat elkeen wat daar teenwoordig is, kon weet dat die heil wat in Jesus Christus gekom het, vir alle volke en nasies geskied het. Dit was vir hulle die sigbare bewys dat die be-• lofte van God eens aan Abraham gemaak "En in jou nageslag sal al die nasies van die aarde geseën word" (Gen 22:18), in vervulling gegaan het. Hierdie hele gebeure op Pinkster sê Petrus het plaasgevind as bewys dat die belofte van Joël 2:28 "En daarna sal Ek my Gees uitgiet op alle vlees", waar geword het (Hand 2:16 e v). Hierdie Gees wat op Pinksterdag uitgestort is, was nie die besit van die apostels alleen nie.

Pas daarna sien ons dat hulle wat in Jesus geglo het en hulle deur die doop in die kerk laat inlyf het, ook die gawe van die Heilige Gees ontvang het (Hand 2:38, 41). Die opvallende by hierdie gebeure is dat daar nie weer sprake is van 'n nuwe uitstorting en spreek in vreemde tale nie. Die Heilige Gees is klaar oor die kerk in Jerusalem uitgestort, dit is bevestig deur die spreek in tale. Hierdie bevestiging is daarom nie meer nodig nie.

Vanaf Jerusalem loop die evangelie oor Judea na die Samaritane. In Handelinge 8:15-17 lees ons dat die Heilige Gees uitgestort is oor die Samaritane. Hierdie uitstorting vind plaas sonder die spreek in vreemde tale. Laasgenoemde was nie meer nodig nie, aangesien die Samaritane in ' $n$ baie groot mate gereken kan word tot ' $n$ deel van die Joodse volk, 'n deel van die gemeente van Jerusalem. Dieselfde redenasie kan aangevoer word ten opsigte van Paulus wat die Heilige Gees ontvang het, sonder die spreek in vreemde tale (Hand 9:17).

As die evangelie by Kornelius en sy huisgesin uitkom, bereik die opdrag van Christus soos vervat in Handelinge 1:8 sy laaste fase. Kornelius as Romeinse kaptein is verteenwoordiger van die volk wat gedurende daardie tyd heerskappy gevoer het oor die ganse bewoonde wêreld van daardie tyd, "die uiterste van die aarde". Uit Handelinge 10 en 11 is dit duidelik dat die Heilige Gees oor hom en sy huisgesin uitgestort is en dat hulle in vreemde tale gespreek het. Langs hierdie weg bevestig God dat die heil in Christus, bestem is vir alle volke en nasies van daardie tyd en alle tye.

Op daardie stadium kan ons sê, is die Heilige Gees uitgestort oor 
elke denkbare groep gelowiges. Die enigste wat nog buite gestaan het, is die dissipels van Johannes. In Handelinge 19:6 kom hulle ook in die ligkring. Die Gees word oor hulle uitgestort en hulle spreek in tale.

Hierna is die evangelie deur Paulus en ander uitgedra oor feitlik die hele bewoonde aarde van daardie tyd. Die opvallende is: Nêrens word melding gemaak van die Heilige Gees wat weer uitgestort is en begeleidende tekens wat gevolg het nie. Nêrens word in die Bybel opdrag gegee dat die gelowiges met die Heilige Gees gedoop moet word en in vreemde tale moet spreek nie. Wanneer Paulus later sy briewe aan die verskillende gemeentes skryf, spreek hy asof die Gees in sy ganse volheid reeds klaar oor al die gemeentes uitgestort is. (Vergelyk die seëngroet aan die einde van die briewe.) Paulus kan so spreek omdat hy glo en weet dat die uitstorting van die Heilige Gees oor die kerk klaar en vir altyd plaasgevind het. Die uitstorting van die Heilige Gees is net soos Christus se kruisiging 'n eenmalige onherhaalbare daad, net so die spreek in vreemde bestaande tale wat die uitstorting begelei het.

Die begrip "vervul met die Heilige Gees" word ook dikwels gebruik om te betuig dat die Heilige Gees opnuut oor elke gelowige uitgestort moet word. Besondere ondersoek na hierdie begrip is daarom noodsaaklik.

Veral in die Ou Testament beteken "vervul" om vol te maak of vol te word (II Kron 5:13; Ps 72:18). Dit word ook gebruik in die sin van: die Skrifte is vervul, met verwysing na dit wat veral deur die profete gesê is (Matt 1:22, 2:15, 4:14, 8:17, 26:54; Mark 14:49 en Joh 13:18). Vanuit hierdie betekenis kan ons sê: "Vervul word met die Heilige Gees" beteken: Dit wat eenmaal gesê is aangaande die Heilige Gees het tot volle werklikheid geword. As ons nou die woorde van Jesus Christus uit Johannes 14 tot 16 ten opsigte van die Heilige Gees in verband bring, kan ons sê "vervul word" met die Heilige Gees beteken: Kom tot die volle geloof in Jesus Christus, is oortuig van sonde, geregtigheid en oordeel, word gelei in die hele waarheid van Christus. Hierdie besondere betekenis kom duidelik na vore in Efesiërs 3:16-19: "Dat Hy aan julle mag gee na die rykdom van sy heerlikheid om met krag versterk te word deur sy Gees in die innerlike mens, sodat Christus deur die geloof in julle harte kan woon, julle wat in die liefde gegrond en gewortel is, en julle in staat kan wees om saam met al die heiliges ten volle te begryp wat die breedte en lengte en diepte en hoogte is, en die liefde van Christus te ken wat die kennis oortref, sodat julle vervul kan word tot al die volheid van God". Hierby sluit Kolossense 1:9 aan: "Daarom hou ons nie op nie, van die dag af dat ons dit gehoor het, om vir julle te bid en te vra dat julle vervul mag word met die kennis van sy wil in alle wysheid en geestelike 
insig, sodat julle waardiglik voor die Here mag wandel om Hom in alles te behaag en julle in elke goeie werk vrug mag dra en in die kennis van God mag groei. (Vergelyk ook Kolossense 4:12.)

Die gevolg van vervul wees met die Heilige Gees bestaan volgens Efesiërs 5:18 uit: "Spreek onder mekaar met psalms en lofsange en geestelike liedere; en sing en psalmsing in julle harte tot eer van die Here, terwyl julle God die Vader altyd vir alles dank in die Naam van ons Here Jesus Christus.

'n Besondere aspek wat duidelik na vore kom in die begrip "vervul met die Heilige Gees" is dat die persoon wat vervul is vrymoedig spreek aangaande die verlossing in Jesus Christus (Luk 1:14, 1:67; Hand 4:8, 4:31, 9:17, 13:9). Uit Handelinge 4:8 en 4:31 is dit duidelik dat iemand by meer as een geleentheid vervul kan word met die Heilige Gees. Hier is nie sprake van 'n weer uitstort van die Heilige Gees nie, maar slegs 'n besondere toerusting wat op besondere geleenthede verleen word om vrymoedig te spreek aangaande Jesus Christus, soos Hyself beloof het (Matt 10:19, 20). So 'n besondere toerusting, met besondere geleenthede, word ook uitgedruk deur die begrip "vol van die Heilige Gees". (Vergelyk Handelinge 6:3, 11:24.)

In Efesiërs 5:18 word die begrip "vervul met die Heilige Gees" aangetref in die vorm van 'n bevel. In die lig van die voorafgaande sal dit beteken: Die gelowige moet ernstig bid en begeer dat God so met sy Gees in Hom sal werk dat hy die verlossing in Jesus Christus ten volle sal glo, dat hy volkome sal leef ooreenkomstig die Woord van God, dat God hom bekwaam sal maak om sy Woord met vrymoedigheid te spreek. Aangesien die Heilige Gees oor die kerk uitgestort is, en die werking van die Heilige Gees en die verkondiging van die kerk onlosmaaklik aan mekaar verbonde is (Hand 2:14-41, 8:26-40; Rom 10:17), beywer die gelowige hom vir die vervulling met die Heilige Gees, as hy voortdurend in die ruimte van die kerk staan onder die geklank van die gepredikte Woord en die gebruik van die sakramente. (Vergelyk Heidelbergse Kategismus Sondag 25, vraag en antwoord 65.)

\section{Konklusie}

"Doop met die Heilige Gees" is die belofte van die uitstorting van die Heilige Gees wat met Pinkster in vervulling gegaan het; die uitstorting gaan gepaard met spreek in bestaande tale om te bevestig dat die Gees waarlik uitgestort is; die uitstorting met die spreek intale is ' $n$ eenmalige, onherhaalbare daad; "vervul met die Heilige Gees" is om ten volle deel te hê aan al Christus se weldade, veral die gawe om sy waarheid met vrymoedigheid te spreek. Hierdie spreke vind volgens al die tekste plaas in die taal van die spreker.

Omdat die meeste van ons lidmate nie die gawes van die Gees op 
so 'n wonderbaarlike wyse soos die pinkstergroepe "ervaar" nie, heers die vraag by hulle: Is ek waarlik'n gelowige? Is die feit dat ek formeel lidmaat van die kerk is, voldoende bewys dat ek ook die gawe van die Heilige Gees besit?

God het wel sy Gees oor die kerk uitgestort maar dit beteken nie dat elkeen wat deel is van die kerk die gawe van die Heilige Gees besit nie. In die midde van die kerk kan ongelowiges voorkom net soos daar buite. Uit die bespreking wat reeds gevoer is, is dit duidelik dat die geloof in Christus en die daarby behorende lewe van dankbaarheid in gehoorsaamheid aan sy Woord, gawe van die Heilige Gees is. As ek glo in Christus en my hele lewe getuig van hierdie geloof, is ek waarlik 'n Christen en dan het ek deel aan die gawe van die Heilige Gees. As ek waarlik in Christus glo, behoort die vrug van die Gees in my lewe sigbaar te wees. Die vrug van die Gees is: "Liefde, blydskap, vrede, lankmoedigheid, vriendelikheid, goedheid, getrouheid, sagmoedigheid en selfbeheersing" (Gal 5:22). In I Korintiërs 13 word veral die liefde by uitnemendheid geteken as vrug van die Gees. As ek waarlik God en my naaste lief het en hierdie liefde is gevul met die besondere inhoud wat die Bybel daaraan gee, is ek gelowige. Dan het ek deel aan die gawe van die Heilige Gees, al ontbreek besondere ekstatiese ervarings en die spreek in tale in my lewe.

\section{Besondere gawes van die Heilige Gees}

Naas die gewone gawes, word in die Nuwe Testament melding gemaak van besondere gawes van die Heilige Gees. Hierdie besondere gawes word vertaal met "genadegawes" (garisma of garismata). 'n Genadegawe is iets wat iemand ontvang sonder enige verdienste van sy kant. Veral die Ou-Testamentiese ekwivalent van genade stel dit duidelik. Die selfstandige naamwoord "genade" (chen) is afkomstig van 'n werkwoord met die stam "hnn" in die Hebreeus wat beteken "genadig wees, erbarm" neerbuig om neer te buig, van bo na benede; van die meerdere na die mindere, van God na die mens. ' $n \mathrm{Ge}$ nadegawe word deur God aan die mens geskenk, maar word nooit deel van die mens se syn nie. God kan dit weer van die mens wegneem as dit Hom behaag.

Die woord "garisma" of genadegawe kom sewe en twintig maal voor in die Nuwe Testament, twintig keer in die enkelvoud en sewe keer in die meervoud. Dié woord word hoofsaaklik deur Paulus gebruik, slegs een maal deur Petrus. Baie keer gebruik Paulus die woord sonder om nader aan te dui waarin of waaruit die genadegawe bestaan. By ' $n$ algemene vergelyking van die tekste waarin die woord sonder enige nadere aanduiding voorkom, lyk dit of Paulus daaronder verstaan: die verlossing in Jesus Christus en alles wat daarmee in verband staan. 
Volgens I Korintiërs 12:4 is dit die Heilige Gees wat die genadegawes gee. In die Evangelies kan daar daarom nog nie sprake wees daarvan nie, aangesien die Heilige Gees nog nie uitgestort is nie. In Handelinge kom die woord genadegawe nie voor nie, wel die saak. Dit is eers Paulus wat hierdie woord uit die Hellenisme oorneem en in die Nuwe-Testamentiese literatuur inbring.

In die meeste gevalle blyk dit dat die genadegawes aan enkele gelowiges gegee is (I Pet 4:10; I Kor 7:7; I Tim 4:14; II Tim 1:6). Slegs in een geval is dit aan 'n groep persone naamlik die volk Israel gegee (Rom 11:29). Hier word God se liefde, sy uitverkiesing van die volk Israel aangedui met die Woord genadegawe. Uit alle gevalle blyk dit egter dat die Heilige Gees dit gee aan wie $\mathrm{Hy}$ wil en in die mate waarin Hy dit nodig ag.

Volgens Romeine 1:11 gee die Heilige Gees die genadegawes "sodat julle versterk kan word." Onder versterking is baie dinge verstaan: die geestelike versterking wat daar van die apostoliese prediking uitgegaan het; versterking te midde van vervolgingsgevare. (Vergelyk Filippense 1:29). Volgens I Petrus 4:10 is dit gegee om mekaar daarmee te dien. Dien beteken om beskikbaar te wees vir mekaar, bereid te wees om te gee. Die genadegawe is aan die enkeling gegee ter wille van die geheel van die gemeente. Omdat dit gegee is, verhef dit die besitter nie bo die ander wat dit nie het nie, maar spoor hom eerder aan om in nederigheid die hele gemeente daarmee te dien. In die besonder is die genadegawes gegee tot opbouing van die gemeente. (Vergelyk Efesiërs 4:12-14; I Korintiërs 14:4.) Enersyds lei dit daartoe dat ongelowiges tot die gemeente toegevoeg word, andersyds dat die wat reeds glo se geloof in Jesus Christus nog verder versterk word. Volgens I Korintiërs 13 is die genadegawes sinneloos sonder die liefde. Die genadegawe is, uit liefde, deur God gegee en dit moet die ontvanger dwing om God en sy naaste lief te hê. Dit is daarom altyd in die eerste plek gegee ter wille van die eer van God.

In vier gedeeltes gee Paulus ' $n$ opsomming van die verskillende genadegawes (Rom 12:6-8; I Kor 12:8-10, 12:28-30; Ef 4:11). Op ander plekke word afsonderlike genadegawes genoem (Rom 5:15, 16, 6:23; I Kor 7:7).

Vervolgens sal ons elke genadegawe wat in genoemde tekste vermeld word afsonderlik bespreek:

\section{Profesie (Rom 12:7; I Kor 12:10, 29; Ef 4:11)}

Die genadegawes van profesie kom voor in al die gedeeltes waar sprake is van die besondere gawes (Rom 12:7; I Kor 12:10, 14; Ef 4:11). Die werklike betekenis van die profesie is deur die eeue heen wyd gediskuseer. Enersyds word geoordeel dat die profesie 'n gawe 
is wat net voorgekom het gedurende die eerste periode van die kerk op aarde. Andersyds word geoordeel dat die woord profesie nie altyd gebruik is nie, maar dat die saak altyd voorgekom het. Die profete in die eerste Christelike gemeente "were the agents by which the Holy Spirit declared God's will or revealed coming events to the church" (Richardson bl 335). Die profete was mense wat kragtens 'n besondere gawe "hic et nunc het Woord Gods brachten (Ridderbos Kommentaar op Efesiërs 4:11). Op de Konvent van Wezel 1568 is geoordeel dat die profesie die gawe van wetenskaplike uitleg van die Skrif is (Lekkerkerker Kommentaar op Romeine bl 114-115). Dit is die gawe om "Gods wil aan die gemeente te kan verkondig" (Jonker, Kommentaar op Romeine bl 168). "By Paul understands intelligibly preaching that builds up the church" (Interpreters Bible Vol 3, bl 919). Professor Bavinck is van oordeel dat die beste verklaring van wat profesie is, vir ons gegee word in I Korintiërs 14:3: "Hy wat profeteer spreek vir die mense woorde van stigting en troos en bemoediging." Op grond hiervan kom Abbot tot die konklusie dat profesie eintlik die gawe van die prediking is. In die lig van die besondere betekenis wat die profesie in die Ou Testament inneem, kan ons dit miskien verklaar met: die bekendmaking en verklaring van die wil van God. Uit Handelinge 2:17 blyk dat die Woord profesie op 'n besondere en op ' $n$ algemene gawe dui. Enersyds is dit 'n aanduiding van die gawe wat God vir alle gelowiges gegee het om Hom te ken en te spreek aangaande Hom. Andersyds dui dit op die besondere gawe om God se Woord te verkondig in die sin van prediking.

Die profesie moet geskied na die maat van die geloof (Rom 12:7). Elkeen kan nie die Woord van God verklaar volgens sy eie norme en insigte nie, dit moet geskied ooreenkomstig die reeds bestaande en aanvaarde geloofsuitsprake (die regula fidei). Volgens I Korintiërs 14:29 moet twee of drie profete spreek en ' $n$ ander een moet dit beoordeel. Daar moet absoluut seker gemaak word dat die waarheid gespreek word en nie 'n selfuitgedinkte versinsel aan die gemeente voorgehou word nie. Op grond hiervan sê Petrus dat die profesie eers moontlik is nadat noukeurig "nagevors" en ondersoek is "op watter of hoedanige tyd die Gees van Christus wat in hulle was, gewys het" (I Pet 1:10).

\section{Bediening (Rom 12:7)}

Dit is die gawe om mense se nood te begryp en hulle midde in hulle nood by te staan en te help. Enersyds word gesê dat die bediening dui op algemene dienste in die gemeente, sonder dat dit op georganiseerde wyse geskied. Andersyds word geoordeel dat die begrip bediening hier reeds op die amp van die diaken dui. Dit moet geskied in die "werk van bediening". Die bediening moet geskied met die 
regte motief. Egoïsme of selfverdienste mag nie die dryfveer wees nie, maar geloof en dankbaarheid.

\section{Leer (Rom 12:7; I Kor 12:29)}

Dit is die gawe om vanuit die Skrif op deeglike en begrypende wyse onderrig te gee aan ander. Die inhoud en die sentrum van hierdie "leer" is Jesus Christus. Die meeste kommentare is dit eens dat die begrip "leer" wys op die amptelike onderrig, die kategese soos ons dit vandag in die kerk beoefen. Professor Karl Barth wil dat die leer aanduiding sal wees van die werksaamhede van die teologiese professor (Romeine Kommentaar, bl 447).

\section{Vermaan (Rom 12:8)}

Die vermaning of die vertroosting dui in die besonder op die pastorale werksaamheid van die dienaar van die Woord. Vanweë sy verband met die profesie (I Kor 14:3, 31) en sy verband met die leer (Ef $4: 11$ ) is die vermaning ook inbegrepe by die prediking en die kategese.

\section{Uitdeel (Rom 12:8)}

'n Noue ooreenkoms bestaan tussen die begrip uitdeel en bediening. "Bediening" is aanduiding van hulpverlening op elke denkbare wyse. "Uitdeel" spreek meer van ontferming op materiële vlak. Die hele gedagtegang is: God gee aan jou. Uit dankbaarheid is jy geroep om aan ander te gee. Sommige verklaarders is van oordeel dat die "uitdeel" spreek van die diakonale arbeid op geordende wyse binne in die gemeente.

\section{Voorganger (Rom 12:8)}

Dit is aangewese persone wat met trou en ywer leiding gee op elke terrein van die kerklike lewe (I Tess 5:12; I Tim 5:17). Hulle besit die bekwaamheid om in die gemeente voor te gaan wanneer dit ookal nodig mag wees. Veral in allerlei situasies, ondernemings en vergaderings het hierdie mense die gawe om alles dadelik op te som, dit saam te vat en te sien waar dit presies op aankom. Dit kan ook beteken: iemand wat opkom vir die reg van die weerloses byvoorbeeld die weduwees, wese, slawe ensovoorts. Hierdie voorganger verrig sy werk met ywer.

Barmhartigheid bewys (Rom 12:8)

Hierdie gawe stem nou ooreen met die gawes van bediening en uit- 
deling. Dit is waarskynlik die versorging van hulle wat besondere hulp nodig het soos die siekes, weduwees, wese, oues van dae, armes ensovoorts. Hierdie barmhartigheid moet met blymoedigheid bewys word.

\section{Konklusie}

Alle gawes moet in diens van God gebruik word sonder bymotiewe of begeertes tot eie gewin; al die genoemde gawes lê op die vlak van die gewone, die alledaagse; nadere ontleding toon 'n noue ooreenkoms met die ampte soos ons dit in Paulus se Pastorale briewe aantref, soos dit beskryf is in die Nederlandse Geloofsbelydenis (Artikel 30) en soos dit vandag nog in gevestigde Protestantse kerke funksioneer. Professor Bavinck sê onder andere: $\mathrm{Al}$ die genoemde gawes lê op die rand van die ampte (Bavinck, Ik geloof in de Heilige Geest, bl 58).

In Paulus se eerste brief aan die Korintiërs kom enkele gawes voor wat ons nie in sy Romeine brief aantref nie. Hierdie enkeles sal in die volgende paragraaf nader bespreek word:

Woord van kennis en woord van wysheid (I Kor 12:8)

Dit is moeilik om ' $n$ onderskeid te maak tussen die twee gawes. Volgens Bavinck is wysheid ' $n$ aangebore gawe, kennis aan die anderkant is die produk van nadenke en studie (Bavinck, a w bl 62).

\section{Geloof (I Kor 12:9)}

Volgens Efesiërs 2:8 is geloof 'n gawe van die Heilige Gees. Sommiges oordeel "geloof" is hier die suiwer saligmakende geloof. Ander sien "geloof" in hierdie konteks as die geloof wat jou in staat stel om wonders te verrig.

\section{Gesondmaking (I Kor 12:9, 28, 30)}

Uit die wyse waarop Paulus die woord of begrip gebruik naamlik sonder omskrywing, blyk dit dat die gemeente goed bekend was daarmee. Uit die woordgebruik volg dat aan 'n skielike herstel van bepaalde siektes gedink moet word. Baie omskryf die gesondmaking as genesings soos ons dit by Christus en die apostels aantref. Plummer in sy kommentaar op I Korintiërs sê dat die gesondmaking kon geskied bloot deur die gebed of deur middel van natuurlike middels soos ons ook lees in Jakobus 5:4 (Kommentaar op I Korintiërs, bl 266). Hoe die gesondmaking geskied het, word nie gesê nie. 
Sommiges oordeel dat hieronder verstaan moet word: besondere krag wat iemand ontvang het om wonders te doen en demone uit te dryf. Ander omskryf dit gewoon as besondere krag om te werk in die koninkryk van God, byvoorbeeld in die geval van Paulus (Grossheide, Kommentaar op I Korintiërs bl 326).

\section{Onderskeiding van geeste (I Kor 12:10)}

Van besondere belang is dat hierdie gawe naas die van profesie genoem word. In die lig van I Korintiërs 14:29 kan gesê word dat hierdie die gawe is om toesig of opsig te hou of die profesie waaragtig is. Gedurende die eerste eeue was die Woord nog nie op skrif gestel nie. Belydenisgeskrifte het ook nog nie bestaan nie. Voortdurend is die gemeentes geteister deur valse leraars (I Joh 4:1). Mense met bogenoemde gawe kon onderskei tussen die ware en die valse leer.

\section{Allerhande tale (I Kor 12:10)}

Apreek in tale of "glossolalie" was 'n godsdienstige verskynsel wat in die ou wêreld en hedendaags binne en buite die Christendom voorkom (Kempff Praktiese Teologe Kongres, referaat). Hoedanig dit presies was, kan nie gesê word nie. Volgens die meeste verklaarders klink dit vir die hoorders na 'n onverstaanbare brabbeltaal en is beslis geen bestaande taal nie. Dit moet gevolglik onderskei word van die vreemde tale wat op Pinksterdag gespreek is.

\section{Uitleg van tale (I Kor 12:10)}

Dit is 'n afsonderlike gawe naas die "glossolalie". Dit kan dieselfde persoon wees wat spreek in die taal en dit uitlê (I Kor 14:5) of dit kan ook iemand anders wees (I Kor 14:28).

In bogenoemde lys van gawes vermeld Paulus ook die profesie. In I Korintiërs 28 tot 30 gee Paulus weer' $n$ lys van besondere gawes. Behalwe die reeds genoemdes vermeld Paulus nog die gawe van die apostelskap. Sonder om breed hieroor te praat kan gesê word: Apostels was mense wat Christus self geroep het, wat Christus self gesien en gehoor het en later getuies geword het van sy lewe en werk. Sonder enige uitsondering meld alle kommentare dat hulle amp eenmalig was.

In Efesiërs 4:11 noem die apostel Paulus weer 'n lys van gawes op: apostels, profete, evangeliste, herders en leraars. Dit is almal gawes wat God in die begintyd en deur die eeue heen gebruik het ter wille van die verkondiging van sy Woord. 


\section{Beoordeling}

In al drie die gedeeltes waar die gawes genoem word, kom dié voor wat in direkte verband staan met die verkondiging van die Woord; in Romeine en Korintiërs dié wat in verband staan met die opsig oor die Woordverkondiging en die barmhartigheidsdiens; slegs in die gedeeltes uit Korinte kom besonder buitengewone gawes soos spreek in tale en gesondmaking voor. Die kerk sal 'n baie duidelike antwoord moet gee op die volgende vrae: Kan en wil God tot vandag toe al die genoemde gawes gebruik in sy diens tot uitbouing van sy koninkryk?

Die vraag of God kan, sal sondermeer as bevestigend beantwoord moet word. God is die Almagtige en alles is daarom sondermeer vir Hom moontlik. Bloot die feit dat 'n besondere gawe vandag nog onder sekere groepe funksioneer, is egter nie voldoende bewys dat dit die wil van God is nie. Dit wat dikwels aangegee word as Christelik kan net sowel heidens en demonies wees. Net soos Moses en Aäron het Farao se towenaars ook tekens en wonders gedoen (Eks 7, 8). In Handelinge 16 tref ons 'n slavin met 'n waarsêende gees aan. In die laaste dae sê Christus "sal daar valse christusse en valse profete opstaan, en hulle sal groot tekens en wonders doen" (Matt 24:24). (Vergelyk ook Openbaring 13:13, 14, 16:14.) Die antichris wat Paulus in II Tessalonisense 2:9 beskryf se koms sal gepaardgaan met "allerhande kragtige dade, tekens en wonders van die leuen." Vir ons as gelowiges bestaan nie die moontlikheid om te bespiegel of God kan of wil nie. Vir ons geld alleen wat wil God. Die wil van God is egter nie geleë op ons bespiegelingsveld nie, maar is vir ons opgeteken in die Woord van God, die Bybel. Die sektariese weg om een Bybelgedeelte te verhef as die alleenprekende sal afgewys moet word. Die ganse Skrif in sy regte verband sal tot spreke gebring moet word; die Bybel gee nê rens in een teksvers of een hoofstuk ' $n$ klinkklare antwoord op ons vraag nie. Uit die gegewens voorhande sal uit die hele Skrif 'n gevolgtrekking gemaak moet word;

die vraag kan soos volg geformuleer word: Watter gawes tref ons aan in die Skrif as blywend; watter gawes word in die Skrif spesifiek beveel; aan watter gawes heg die Skrif self die hoogste waarde en vir watter gawes moet die gelowiges hulle beywer?

In die verband gee ons aan die volgende aandag:

\section{Die gawe van die profesie}

Hierdie gawe tref ons aan in al drie die Skrifgedeeltes waar in die besonder melding gemaak word van die genadegawes. Hierdie gawe soos reeds geblyk, is die verkondiging van die Woord van God. As Christus, voor sy hemelvaart opdrag aan sy apostels gee, staan die 
verkondiging van die Woord in die sentrum (Matt 28:19; Hand 1:8). As ons kyk na die werk van die apostels soos beskryf in Handelinge en die Briewe is dit duidelik dat die verkondiging altyd sentraal gestaan het (Hand 6:2). Na die dood van die apostels gaan die werk van die kerk voort. Veral in sy Pastorale briewe gee Paulus opdrag hoe die kerk in die wêreld moet funksioneer. Besondere klem word weer eens gelê op die verkondiging van die Woord (I Tim 4:11; II Tim 1:13, 2:2, 4:2). Dat die verkondiging van die Woord hierdie besondere, sentrale plek inneem, is eintlik vanselfsprekend. Dit gaan in die kerk primêr om die geloof in Jesus Christus. Hierdie geloof skenk God op 'n bepaalde wyse. Volgens die hele boek Handelinge skenk God dit deur die verkondigde woord. Die apostels Paulus stel: Die geloof is deur die gehoor van die Woord (Rom 10:17).

Naas die gawe van die profesie neem die gawes wat rondom die die diens van die barmhartigheid lê, ook 'n sentrale plek in. Christus in sy omwandelinge hier op aarde het klem daarop gelê (Matt 25:31-46). Die apostels besef dat dit deel van die kerk op aarde se werk is. Om hierdie dienswerk te verrig, word die armversorgers gekies, waarvan ons lees in Handelinge 6:1 tot 7. In feitlik elke brief in die Nuwe Testament word die barmhartigheidsdiens vermeld. In twee van die drie gedeeltes waar die besondere gawes vermeld word, kom dit voor. In die Pastorale briewe waar dit gaan om die funksionering van die kerk na die apostoliese tyd, word dit nog in die besonder vermeld (I Tim 3:8-10).

Die gawe van regering of opsig neem in die Nuwe Testament ook 'n besondere plek in. Christus gee self daartoe opdrag (Matt 18:15-20; Joh 21:15-17). Paulus self het telkens teruggegaan na die gemeentes wat hy gestig het, om te kyk of alles nog in orde is. In die gemeentes wat hy besoek het, het hy ouderlinge laat kies (Hand 14:23). In die Pastorale briewe beveel hy vir Titus om van stad tot stad ouderlinge te kies (Titus 1:5). Kragtens die besondere betekenis en funksie van die woord ouderling moet ons onder hierdie ouderlinge seker dienaars van die Woord en regerende ouderlinge verstaan. In die drie gedeeltes waar die buitengewone gawes in die besonder bespreek word, kom die saak van die opsig en die regering ook twee maal voor. As ons nou weer gaan kyk na die besondere gawes, soos dit reeds bespreek is, is dit duidelik, dat al die gawes behalwe die van gesondmaking en spreek in tale onder die drie hoofde: profesie, regeringe en barmhartigheid ingedeel kan word.

Die gawes van verkondiging, regering en barmhartigheidsdiens word in die Skrif beskryf as van besondere waarde en blywend. Op grond hiervan het die kerk van die vroegste tye af geoordeel dat dit die besondere wyse is waarop God sy kerk wil laat regeer in die wêreld. "Ons glo dat hierdie ware kerk geregeer moet word volgens 
die geestelike regering wat ons Here ons geleer het in sy Woord, naamlik dat daar dienaars of herders moet wees om die Woord van God te spreek en die sakramente te bedien; ook opsieners en diakens om saam met die herders as die Raad van die kerk te wees en deur hierdie middel die ware godsdiens te onderhou en te sorg dat die ware leer sy loop het, dat ook die oortreders op geestelike wyse gestraf en in toom gehou word, en dat ook die armes en bedruktes gehelp en getroos word na die maat van hulle behoeftes" (Nederlandse Geloofsbelydenis 30). Die gawes wat in die Bybel aanvanklik beskryf is as besondere gawes (garismata) het by ons vanweë die voortdurende bestaan tot gewone en alledaagse geword.

\section{Spreek in tale}

Die gawes van spreek in tale en gesondmaking vra nog in die besonder ons aandag.

Christus self gee nie opdrag dat die gemeente in tale moet spreek nie. Die enigste teks wat wys in hierdie rigting is Markus 16:17. Alle gesaghebbende Nuwe-Testamentici is dit egter eens dat die laaste gedeelte van Markus nie outentiek is nie. Die apostels eis dit ook nie van die gemeentelede waar hulle die Woord verkondig het nie. Dit kom nie voor onder die besondere gawes wat vermeld word in Paulus se brief aan die Romeine en die Efesiërs nie. Dit word nie vermeld in die Pastorale briewe wat die funksionering van die kerk in die na-apostoliese tyd, beskryf nie. Dit kom net voor in die gemeente van Korinte en word laaste gemeld in die lys van besondere gawes. Gedurende die kerk se geskiedenis tot vandag, het dit net sporadies voorgekom;

daar is miskien ' $n$ besondere rede waarom dit net in Korinte voorgekom het. Die gemeente in Korinte leef in ' $n$ gebied waar die misterie godsdienste ' $n$ besondere plek ingeneem het. Onder hierdie godsdienste was daar groepe wat sterk die klem gelê het op die spreek in tale. Miskien was die gemeente in Korinte jaloers op hulle. Die voortdurende begeerte om in tale te spreek, het miskien vanweë psigologiese tendense, die begeerte tot werklikheid gemaak;

in I Korintiërs 14:18 sê Paulus dat hyself in tale spreek. Nêrens op een plek in die Nuwe Testament lees ons dat Paulus hierdie gawe van hom in die midde van die gemeente beoefen het nie. In die volgende vers sê hy ook dat hy dit nie in die gemeente wil beoefen nie. Paulus het waarskynlik hierdie gawe van hom in sy binnekamer ontplooi. As iemand miskien hierdie gawe het, behoort hy dieselfde pad te loop as Paulus. Hy behoort so beskeie daaroor te wees dat niemand anders eers moet weet dat hy hierdie gawe besit nie;

die waarde van spreek in tale in die midde van die gemeente ag Paulus besonder laag. In die kerk gaan dit om die stigting, die op- 
bouing van die gemeente. Die gawe wat in die besonder daarvoor bedoel is, is die profesie, die verkondiging van die Woord (I Kor 14:3). Die leer, die onderrig wat deel is van die verkondiging skat hy tweeduisend maal hoër as die spreek in tale. "In die gemeente wil ek liewer vyf woorde met my verstand spreek om ook ander te onderrig, as tienduisend woorde in ' $n$ taal" (I Kor 14:19). God wil dat die mens in die besonder deur die verkondiging van die Woord tot die geloof sal kom. Na die spreek in tale sal die mense nie luister nie (I Kor 14:21). In plaas daarvan dat die spreek in tale daartoe lei, dat ongelowiges hulle by die gemeente kom voeg, sal dit eerder tot gevolg hê dat die gemeente' $n$ bespotting in die oë van die wêreld sal wees. "As die hele gemeente dan saam vergader het, en hulle sou almal in tale spreek en daar kom onkundiges of ongelowiges binne, sal hulle nie sê dat julle kranksinnig is nie" (I Kor 14:23)? Volgens I Korintiërs 14:20 is hulle wat in tale spreek eintlik kinderagtig. Vanweë al hierdie tendense lei die spreek in tale eintlik tot wanorde in die gemeente. Die Skrif eis dat alles in die gemeente ordelik moet verloop (I Kor 14:40).

\section{Wonders en gesondmaking}

Rondom hierdie saak het die pinkstergroepe en die Nuwe Pentacostaliste ' $n$ hele teologie opgebou: Siekte is die gevolg van sonde, Christus het die sonde oorwin en daarmee saam ook die siekte en alles wat daarmee in verband staan. Elkeen wat waarlik glo in Christus behoort nie meer siek te wees nie. Die gebruik van enige middel om jou siekte weg te neem, is sonde. Die feit dat Christus en sy apostels siekes genees het, word besou as 'n rede waarom die kerk hom ook daarvoor moet beywer.

Om die werk van Christus en sy apostels sondermeer gelyk te stel met die kerk en die gelowiges van vandag is in stryd met elke bestaande hermeneutiese reël. Christus en sy apostels is nie ons voorbeeld nie. Christus is die Verlosser uit sonde en dood en sy apostels is die oor-en ooggetuies van hierdie waarheid.

Jesus Christus se wonders en genesings is teken van sy Messiasskap, dit is die vervulling van God se beloftes in die Ou Testament (Jes 35:5, 6). As Jesus Christus blindes laat sien, dowes laat hoor, lammes laat loop, duiwels uitdryf, is dit 'n teken en bewys dat die heilstyd aangebreek het, dat die Messias gekom het (Matt 18:17). Dat die wonders van die apostels dieselfde betekenis het, blyk uit die feit dat hierdie besondere wonders verdwyn nadat die kerk gevestig is, soos getuienis daarvan gegee word in die Pastorale briewe en briewe wat dateer uit die na-apostoliese tyd.

Nêrens gee Christus opdrag aan sy kerk dat hulle wonders moet verrig nie. In Markus 16:18 word wel melding gemaak van duiweluit- 
drywery en gesondmaking. Soos reeds gesê is, word die outoriteit van hierdie gedeelte hoogs betwyfel. As dit miskien wel outentiek sou wees, en Christus verwag werklik van die gelowiges wat daar gesê word, waarom neem die pinkstergroepe dan nie ook slange op nie, waarom is hulle nie ook bereid om gif te drink, soos daar gesê word nie? In die lyste waar die gawes genoem word, word die gesondmaking net in die Korintiërbrief vermeld en net soos die tale ook na die ander gawes.

Christus het ons volkome verlos van alle sonde en ongeregtigheid. Die gevolg van die sonde naamlik die siekte is ook deur Hom weggeneem. Aan laasgenoemde sal die gelowige eers ten volle deel hê met die weerkoms van Christus. Solank as wat hierdie wêreldorde geld, sal selfs die gelowiges nog nood en ellende ken. Paulus sê self: "Ons moet deur baie verdrukkinge in die koninkryk van God ingaan" (Hand 14:22). Paulus self word nie verlos van sy siekte nie (Gal 4:13, 14; I Kor 2:3). Timoteus het blykbaar voortdurend geworstel met allerlei maagkwale (I Tim 5:23). Trofimus word deur Paulus siek agtergelaat in Miléte (II Tim 4:20).

Reeds in die Ou Testament word middels aangewend om siekes te genees. Jesaja sit 'n vyekoek op Hiskia se wonde (II Kon 20). Naäman moet homself sewe maal in die Jordaan was. Elia en Eliza wek dooie kinders op deur hulle oor hulle uit te strek (I Kon 17; II Kon 4). Een van Paulus se reisgenote en skrywer van die boek Handelinge was 'n geneesheer (Kol 4:14). Timoteus en die ouderlinge wat in die Jakobusbrief vermeld word, moet gebruik maak van middels om te genees (I Tim 5:23; Jak 5:14).

In die Korintiërbrief word nie gesê dat die gawe van gesondmaking 'n gawe sonder middels is nie. Die gawe van genesing deur middel van die gebed kan seker vandag nog bestaan. Dat dit deur die kerk beoefen moet word en dat dit moet geskied los van enige middels kan nie uit die Skrif afgelei word nie. Uit Jakobus 5:14 blyk dat vir die siekes gebid moet word, maar dat middele steeds gebruik moet word.

Dit is uit die Skrif baie duidelik dat dit nie die wil van God is dat geloofsgenesing en doen van wonders gebruik moet word as middels om ons geloof te bevestig of om daardeur ander tot die geloof te bring nie. Die geloof is uit die gehoor van die Woord (Rom 10:17). Die saligheid is juis vir hulle beskore wat sonder sigbare tekens nogtans in Jesus Christus glo: "Salig is die wat nie gesien het nie en tog geglo het" (Joh 20:29). Dit wat in die Skrif beskryf is, is genoeg ter wille van ons geloof: "Hierdie is beskrywe dat julle kan glo dat Jesus die Christus is, die Seun van God" (Joh 20:31). In die outyd het God tot die mense gespreek op baie maniere. In die laaste van die dae spreek Hy deur sy Seun Jesus Christus (Hebr 1:1). In Jesus Christus het God alles vir ons gesê wat nodig is vir ons saligheid. 
Aangesien die spreek in tale en die wonderlike genesing deur die gebed in die Skrif 'n saak van sekondêre belang is en van baie geringe waarde, is die ontbreking daarvan in die lewe van 'n gelowige geen saak tot kommer nie, ook geen saak waarvoor die gelowige hom behoort te beywer nie.

Die kerk sal egter vir sy lidmate moet sê: "Beywer julle met die oog op die beste gawes" (I Kor 12:31). In die lig van die voorafgaande sal dit beteken: As jy die gawe van profesie, regering of barmhartigheid het, bring dit tot volle ontplooiing in jou lewe. In afgeleide sin besit elke gelowige hierdie gawe: Spreek daarom voortdurend van die groot dade van God in Jesus Christus; vermaan jou broer of suster wat op die dwaalspoor geraak het; ontferm jou oor alle mense in nood. Bo dit alles beoefen die liefde wat beskryf word as die grootste gawe (I Kor 13). God moet jy liefhê met jou hele wese en jou naaste soos jouself (Matt 22:37-40).

\section{LITERATUURLYS:}

Abbott, T K, A Critical and Exegetical Commentary on the Epistles to the Ephesians and to the Colossians, Edinburg, 1897.

Barth, K, The Epistle to the Romans, translated by E C Hoskyns, London Oxford University Press, 1933.

Bloem, G N, Die Genadegawes in die Nuwe Testament, Hervormde Teologiese Studies, Afd 4, Jaargang 23, N H W Pers, Krugersdorp.

Boerwinkel, F, Kerk en Secte, Boekencentrum N V's Gravenhage, 1959.

Bond, Tydskrif, The Business Men's Voice of S A Eldorado, Honeydew, Transvaal.

Bruce, F F, The Acts of the Apostles, London Tyndale Press, 1965.

Buttrick, G A en Ander., The Interpreter's Dictionary of the Bible. An illustrated Encyclopedia, New York, Abingdon Press, 1962.

Calvijn, J, De Handelingen der Apostelen, vertaal G Wielenga, 1970.

Calvijn, J, Commentaries on the Epistles of Paul to the Galations and Ephesians, translated W Pringle, Wm B Eerdmans, 1948.

Cranfield, C E B, The Gospel according to St Mark, Cambridge University Press, 1963.

De Boor, W, Die Apostelgeschichte, R Brockhaus. Verlag Wuppertal, 1965.

De Boor, W, Der Brief des Paulus an die Römer, R Brockhaus Verlag Wuppertal, 1967.

De Villiers, J L, Spreek in Tale, N G Kerk Uitgewers, Kaapstad-Pretoria, 1974.

Dreyer, J, 'n Dwaallering van ons Tyd, N H W Pers, 1957.

Grosheide, F W, Handelingen, Korte Verklaring der Heilige Schrift, J H, Kok, N V Kampen, 1962.

Grosheide, F W, De Eerste Brief aan de Kerk te Korinthe, Commentaar op het Nieuwe Testament, J H Kok N V Kampen, 1957.

Haenchen, E, Apostel Geschichte, Meyers Kommentar, Hubert Co., Gottingen, 1961.

Hijmans, A, Geloofsgenezing, N V's Gravenhage, 1962.

Jonker, W D, Die Brief aan die Romeine, N G Kerk Uitgewers Kaapstad-Pretoria, 1967.

Kittel, G, Theological Dictionary of the New Testament, Translated by G W Bromiley, Wm B Eerdmans Michigan, 1967.

Kempff, D, Geloofsgenesing en Tongetaal Getoets, Pro Rege Potchefstroom, 1974.

Koolhaas, A A en Emmen E, De Kerk en de Pinkstergroepen, N V's Gravenhage, 1962.

Lekkerkerker, A F N, De Brief van Paulus aan de Romeine G F Callenbach, N V -Nijkerk, 1965.

Lenski, R C H, The Interpretation of the Acts of the Apostles, Augsburg Publishing House, 1961.

Lightfoot, R H, The Gospel Message of St Mark, Oxford University Press, 1962. 
Lombard, E, Goddelike Genesing, Die Kerkbode, Verenigde Kerkblad van die Ned Geref Kerk, 23 Januarie 1974.

Loubser, D, Die omvang en aard van die Charismatiese Bewegings binne die Afrikaanse Kerke, Die Kerkbode, 25 Desember 1974.

Müller, Jac J, Die Vernaamste Sektes in ons Land, N G Kerk Uitgewers, Kaapstad-Pretoria, 1972.

Plummer, A, A Critical and exegetical Commentary on the Epistle of St Paul to the Corinthians, Edinburgh, 1948.

Praktiese Teologie Kongres Referate (Ongepubliseerd) Pretoria, 1975.

Richardson, A, An Introduction to the Theology of the New Testament, SCM Press London, 1958.

Ridderbos, H, De Pastorale Brieven, Commentaar op het Nieuwe Testament, J.H. Kok Kampen, 1967.

Rienecker, F, Der Brief des Paulus an die Epheser, R Brockhaus Verlag Wuppertal, 1968.

Robbertson, A, A Critical and Exegetical Commentary on the first Epistle of St Paul to the Corinthians, Edinburgh, 1911.

Smelik, E L, De Brieven van Paulus aan Timotheus, Titus en Filemon, G F Callenbach, N V Nijkerk, 1961.

Van der Walt, S P, Dwaling en Waarheid, Pro Rege Potchefstroom 1961.

Van Leeuwen, J A C, Markus, Kort Verklaring van de Heilige Schrift, J H, Kok N V Kampen, 1964.

Van Niftrik, G C, Kleine Dogmatiek, G F Callenbach N V Uitgever Nijkerk, 1959. 